\title{
The toxicity of diphacinone (2-diphenylacetyl- 1,3-indandione) to laboratory rats and mice
}

\author{
Tyuzi KusANO* \\ Department of Applied Entomology, Tottori University, Tottori 680
}

(Received: July 14, 1973)

\begin{abstract}
The toxicity of diphacinone (2-diphenylacetyl-1,3-indandione) to rats and mice was determined for its possible use as an indirect anticoagulant rodenticide. The values of oral acute $\mathrm{LD}_{50}$ against the males and females of albino rat were 43.3 and $22.7 \mathrm{mg} / \mathrm{kg}$, and those against the males and females of laboratory mice were 30.0 and $28.3 \mathrm{mg} / \mathrm{kg}$, respectively. The death usually occurred in 1 to 5 days and the increased dose shortened the survival period. In the case of subacute toxicity of diphacinone against mice, 60 to $100 \%$ mortalities were obtained after the successive administrations of diphacinone baits ranging from 0.0005 to $0.02 \%$ for six days. No appreciable relationship between the mortality and the total intake dose was found in the range from 0.6 to $200 \mathrm{mg} / \mathrm{kg}$. Whereas, the subacute toxicity of diphacinone baits against the albino rats was approximately the same as that of coumatetralyl. Majorities of the mice and rats in these subacute toxicity tests died in 4 to 6 days and 4 to 7 days, respectively. The acceptance of the diphacinone baits was good in mice and rats. The oral acute and subacute toxicities of several indirect anticoagulant rodenticides were discussed in comparison.
\end{abstract}

\section{INTRODUCTION}

Warfarin has been widely accepted over the last two decades as an indirect anticoagulant rodenticide for rat control in urban and rural areas because of the safety to non-target animals and high control efficiency to rodents. However, since long treatment period, over 2 weeks, is required to obtain satisfactory results with warfarin baits (Kusano, 1969) and warfarin-resistant rats and mice have been reported recently in Europe (Drummond, 1971; Greaves, 1971) and the United States (Jackson and Kaukei, 1972), coumatetralyl [3( $\alpha$-tetralyl-4-hydroxycoumarin) $]$ is used as a new indirect anticoagulant rodenticide in Japan.

As the preliminary investigation on the practical use of new indirect anticoagulant, diphacinone, in rat control, the author has determined the acute and subacute toxicities

* 草野忠治：鳥取大学農学部応用昆虫学教室（鳥取 市湖山町) of the poison against rats and mice.

\section{Materials AND MeTHODS}

The laboratory animals employed in the present experiments were dd-strain mice (19-32 g) and Wistar strain albino rats $(150$ $420 \mathrm{~g})$. The test compound, diphacinone (2-diphenylacetyl-1, 3-indandione), was in the form of a $0.1 \%$ concentrate in sugar. In all tests diphacinone was used at various concentrations by diluting the concentrate of diphacinone with distilled water a mixture of biscuits powder and wheat flour $(25: 75)$. The diphacinone baits were kneaded by mixing the flour, the $0.1 \%$ diphacinone concentrate and distilled water, and the poison baits of irregular form at the weight from 1.5 to $2 \mathrm{~g}$ per bait were made up.

The oral acute toxicity of diphacinone against the albino rats was determined by a single administration of the poison to the animals with the stomach catheter. The albino rats were offered tap water only for 
24 hours prior to the test and were anesthetized with ether at the time of the test. The mortality was observed for 10 days. The doses were regulated by the administered volume of the poison solution in a concentration of $81 \mathrm{mg} / \mathrm{dl}(81 \mathrm{~g}$ concentrate $/ \mathrm{dl})$. The mice were also tested in a similar way after fasting for 3 hours before the test but the poison was administered without anesthetizing them. The mortality of tested mice was observed for ten days.

The oral subacute toxicity of diphacinone against albino rats was determined by administering $5 \mathrm{ml}$ of the diphacinone solution per $\mathrm{kg}$ body weight at the level of 0.001 to $0.02 \%$ every 24 hours for 5 days. The mortality was observed for 15 days after the first dose.

The subacute toxicity of diphacinone baits against albino rats and mice was determined by the following method. The rats or mice were caged singly and fed on the diphacinone baits ad libitum for a limited number of days after prebaiting with plain baits for one day. The residual poison baits were weighed daily and newly prepared poison baits were offered to them every 24 hours at the rate of $50 \mathrm{~g}$ per rat or $30 \mathrm{~g}$ per mouse. After determining a residual amount of the last poison baits, the mortality was observed for 10 days.

\section{RESULTS}

\section{Acute toxicity}

a) Rats: As shown in Table 1, there was a sex difference in the acute toxicity of diphacinone against albino rats. The males were approximately twice more resistant than the females. The death usually occurred in 1 to 5 days and the survival period was shortened by the increase of dose. Of the rats died within 1 day after one oral dose the severe hemorrhages observed in the brain and the liver, and to a lesser extent in the lungs. Of the rats died in 4 to 10 days after one oral dose, in addition to the same findings the severe hemorrhages were observed in the stomach and the intestine, and the moderate hemorrhages in the testicles and the urinary bladder as well.

b) Mice: The results are given in Table
Table 1 Acute toxicity of diphacinone against albino rats

\begin{tabular}{|c|c|c|c|c|c|}
\hline Sex & $\begin{array}{l}\text { No. of } \\
\text { rats } \\
\text { tested* }\end{array}$ & $\begin{array}{l}\text { Oral } \\
\text { dosage } \\
\mathrm{mg} / \mathrm{kg} \\
\text { B.W. }\end{array}$ & $\begin{array}{l}\text { Morta- } \\
\text { lity } \\
\%\end{array}$ & $\begin{array}{l}\text { Survival } \\
\text { time } \\
\text { Days, m. } \pm \\
\text { S.D. }\end{array}$ & $\begin{array}{l}\mathrm{LD}_{50} \\
\mathrm{mg} / \mathrm{kg} \\
\mathrm{B} . \mathrm{W} .\end{array}$ \\
\hline \multirow{6}{*}{ 今 } & 10 & 20.0 & 0 & & \multirow{6}{*}{$\begin{array}{c}43.3 \\
(34.9- \\
53.7)^{* *}\end{array}$} \\
\hline & 15 & 24.3 & 20 & $5.0 \pm 2.9$ & \\
\hline & 15 & 28.4 & 27 & $4.3 \pm 3.7$ & \\
\hline & 15 & 32.0 & 27 & $2.3 \pm 2.7$ & \\
\hline & 15 & 41.0 & 47 & $1.9 \pm 2.1$ & \\
\hline & 10 & 48.0 & 60 & $1.0 \pm 0.0$ & \\
\hline \multirow{6}{*}{ 오 } & 10 & 4.0 & 0 & & \multirow{6}{*}{$\begin{array}{c}22.7 \\
(19.6- \\
26.3)^{* *}\end{array}$} \\
\hline & 10 & 8.0 & 0 & & \\
\hline & 12 & 16.0 & 20 & $3.5 \pm 1.5$ & \\
\hline & 15 & 20.0 & 47 & $5.1 \pm 1.1$ & \\
\hline & 15 & 24.3 & 47 & $2.0 \pm 1.3$ & \\
\hline & 10 & 32.0 & 90 & $1.0 \pm 0.3$ & \\
\hline
\end{tabular}

* Body weights of albino rats were from 150 to $220 \mathrm{~g}$.

** $95 \%$ confidence limits for $\mathrm{LD}_{50}$.

2. There was no sex difference in the acute toxicity of diphacinone. The $\mathrm{LD}_{50}$ values of diphacinone against the males and females of mice laid between those of the male albino rats and the females. Like the case of rats, majority of the tested mice died in 1 to 5 days and the survival period was shortened with the increased dose. Of the mice died within 1 day after one oral dose, the severe hemorrhages were observed in the brain, the liver and the gall-bladder, and the slight ones in the lungs. Furthermore, the marked abdominal dropsy was observed in many mice. Of the mice died within 4 days after one oral dose, the severe hemorrhages were in the intestine and the liver, and the slight ones in the lungs.

\section{Subacute toxicity}

a) Oral subacute toxicity of diphacinone against the albino rats: As shown in Table 3 , the low mortality of albino rats was obtained after 6 successive administrations in 6 days at the rate of $0.05-1.0 \mathrm{mg} / \mathrm{kg} /$ dose. In autopsy of the dead mice, the hemorrhages were observed in the stomach, the intestine, the liver, the lungs, the thoracic cavity, the testicles, the mouth and the hypodermic area.

b) Subacute toxicity of diphacinone baits 
Table 2 Acute toxicity of diphacinone against mice

\begin{tabular}{|c|c|c|c|c|c|}
\hline Sex & $\begin{array}{c}\text { No. of } \\
\text { mice } \\
\text { tested* }\end{array}$ & $\begin{array}{l}\text { Oral } \\
\text { dosage } \\
\text { mg/kg } \\
\text { B.W. }\end{array}$ & $\begin{array}{l}\text { Morta- } \\
\text { lity } \\
\%\end{array}$ & $\begin{array}{l}\text { Survial } \\
\text { time Days, } \\
\text { m. } \pm \text { S.D. }\end{array}$ & $\begin{array}{l}\mathrm{LD}_{50} \\
\mathrm{mg} / \mathrm{kg} \\
\mathrm{B} . W\end{array}$ \\
\hline \multirow{7}{*}{$\hat{0}$} & 15 & 16.2 & 13 & $3.5 \pm 0.5$ & \multirow{7}{*}{$\begin{array}{c}30.0 \\
(26.0- \\
34.7)^{* *}\end{array}$} \\
\hline & $\prime \prime$ & 20.3 & 27 & $4.8 \pm 1.5$ & \\
\hline & "I & 24.3 & 33 & $2.8 \pm 1.2$ & \\
\hline & 11 & 28.4 & 40 & $3.3 \pm 1.5$ & \\
\hline & $\prime \prime$ & 32.4 & 47 & $1.3 \pm 0.5$ & \\
\hline & $\prime \prime$ & 40.5 & 73 & $1.4 \pm 1.2$ & \\
\hline & $\prime \prime$ & 48.6 & 87 & $1.5 \pm 1.1$ & \\
\hline \multirow{7}{*}{ 우 } & 15 & 16.2 & 0 & & \multirow{7}{*}{$\begin{array}{c}28.3 \\
(25.0- \\
32.0)\end{array}$} \\
\hline & "I & 20.3 & 20 & $3.7 \pm 0.5$ & \\
\hline & $\prime \prime$ & 24.3 & 40 & $4.0 \pm 2.5$ & \\
\hline & " & 28.4 & 47 & $2.9 \pm 1.6$ & \\
\hline & $\prime \prime$ & 32.4 & 53 & $2.0 \pm 1.4$ & \\
\hline & $\prime \prime$ & 40.5 & 80 & $1.3 \pm 0.6$ & \\
\hline & $\prime \prime$ & 48.6 & 93 & $1.0 \pm 0.0$ & \\
\hline
\end{tabular}

* Body weights of mice were from 19 to $24 \mathrm{~g}$.

** $95 \%$ confidence limits for $\mathrm{LD}_{50}$.

against the mice: As shown in Table 4, 60 to $100 \%$ mortalities were obtained with the concentrations of over $0.0005 \%$ and the death of tested mice occurred in 3 to 12 days, although $67 \%$ of the dead mice was found on 6 th and 7 th day. The acceptance of diphacinone baits was good in mice and the intake amount per day was as large as that of
Table 3 Subacute toxicity of diphacinone solution against albino rats after 6 successive administrations, once in every 24 hours

\begin{tabular}{|c|c|c|c|c|}
\hline Sex & $\begin{array}{l}\text { Diphaci- } \\
\text { none } \\
\text { concent- } \\
\text { ration } \\
\%\end{array}$ & \begin{tabular}{|c} 
Oral \\
dosage \\
$\mathrm{mg} / \mathrm{kg} / \mathrm{day}$
\end{tabular} & $\begin{array}{l}\text { No. of } \\
\text { dead } \\
\text { rats/ } \\
\text { tested* }\end{array}$ & $\begin{array}{c}\text { Survival } \\
\text { time } \\
\text { Days }\end{array}$ \\
\hline \multirow{4}{*}{ 今 } & 0.001 & 0.05 & $0 / 5$ & \\
\hline & 0.005 & 0.25 & $0 / 5$ & \\
\hline & 0.01 & 0.5 & $2 / 5$ & 7 \\
\hline & 0.02 & 1.0 & $2 / 5$ & $5-6$ \\
\hline 우 & 0.005 & 0.25 & $0 / 5$ & \\
\hline
\end{tabular}

the plain baits for the first 3 or 4 days. Afterwards, the intake amount of diphacinone baits per day decreased gradually. As shown in Table 5 no mice died in the group of which had taken $1.25 \mathrm{mg} / \mathrm{kg}$ or less. With the intake of 1.3 to $160 \mathrm{mg} / \mathrm{kg}$ the mortality varied from 67 to $100 \%$. Two mice could tolerate the feeding of the high doses from 161 to $200 \mathrm{mg} / \mathrm{kg}$. There was not a definite relationship between the mortality and the total intake dose found in the range from 0.6 to $200 \mathrm{mg} / \mathrm{kg}$. In many individuals of the dead mice, the marked hemorrhages were observed in the intestine and the lungs.

Table 4 Subacute toxicity of diphacinone baits against mice in continuous feeding for 6 days

\begin{tabular}{|c|c|c|c|c|c|c|c|}
\hline Sex & $\begin{array}{c}\text { Diphacinone } \\
\text { concentration } \\
\%\end{array}$ & $\begin{array}{c}\text { Intake of } \\
\text { plain bait } \\
\mathrm{g}(\text { wet base) } \\
\text { day }\end{array}$ & $\begin{array}{l}\text { Total intake } \\
\text { of poison bait } \\
\text { for six days } \\
\mathrm{g} \text { (wet base) } \\
\mathrm{m} \pm \mathrm{S} \text {.D. }\end{array}$ & $\begin{array}{l}\text { Dose taken } \\
\text { per day } \\
\text { mg/kg, m. } \\
\text { S.D. }\end{array}$ & $\begin{array}{l}\text { Total dose } \\
\text { taken } \\
\text { mg/kg, m.土 } \\
\text { S.D. }\end{array}$ & $\begin{array}{l}\text { No. of dead } \\
\text { mice/tested* }\end{array}$ & $\begin{array}{l}\text { Survival time } \\
\text { Days, m. } \\
\text { S.D. }\end{array}$ \\
\hline \multirow{6}{*}{ 今 } & 0.0001 & $5.6 \pm 0.9$ & $37.7 \pm 3.9$ & $0.15 \pm 0.02$ & $0.92 \pm 0.10$ & $0 / 5$ & \\
\hline & 0.0005 & $4.6 \pm 0.8$ & $30.9 \pm 8.4$ & $0.71 \pm 0.11$ & $3.86 \pm 0.91$ & $4 / 5$ & $5.5 \pm 1.1$ \\
\hline & 0.001 & $5.1 \pm 0.4$ & $28.1 \pm 5.3$ & $1.77 \pm 0.22$ & $10.03 \pm 2.26$ & $5 / 5$ & $6.2 \pm 2.1$ \\
\hline & 0.005 & $5.7 \pm 0.3$ & $28.4 \pm 8.7$ & $5.83 \pm 1.43$ & $34.06 \pm 12.96$ & $3 / 5$ & $6.3 \pm 1.2$ \\
\hline & 0.01 & $7.4 \pm 0.3$ & $27.9 \pm 6.2$ & $13.66 \pm 1.06$ & $70.81 \pm 13.18$ & $5 / 5$ & $6.4 \pm 2.2$ \\
\hline & 0.02 & $6.9 \pm 0.4$ & $27.9 \pm 6.1$ & $34.12 \pm 6.40$ & $172.31 \pm 36.40$ & $5 / 5$ & $8.0 \pm 2.1$ \\
\hline \multirow{5}{*}{ 오 } & 0.0005 & $5.2 \pm 1.0$ & $28.6 \pm 9.5$ & $0.73 \pm 0.15$ & $4.08 \pm 1.40$ & $3 / 5$ & $7.0 \pm 3.7$ \\
\hline & 0.001 & $5.6 \pm 0.8$ & $32.1 \pm 4.1$ & $1.65 \pm 0.22$ & $9.91 \pm 1.33$ & $4 / 5$ & $6.5 \pm 0.9$ \\
\hline & 0.005 & $7.0 \pm 0.8$ & $26.7 \pm 7.9$ & $6.86 \pm 1.69$ & $39.80 \pm 10.56$ & $4 / 5$ & $6.5 \pm 1.5$ \\
\hline & 0.01 & $6.8 \pm 0.3$ & $27.8 \pm 7.3$ & $13.71 \pm 4.25$ & $79.21 \pm 25.03$ & $3 / 5$ & $5.7 \pm 0.5$ \\
\hline & 0.02 & $6.9 \pm 0.4$ & $23.1 \pm 7.1$ & $23.85 \pm 6.39$ & $139.93 \pm 42.60$ & $3 / 5$ & $5.7 \pm 0.5$ \\
\hline
\end{tabular}

* Body weights of mice ranged from 22 to $32 \mathrm{~g}$ 
Table 5 Relationship between the total dose taken and the mortality of mice in continuous feeding of diphacinone baits

\begin{tabular}{|c|c|c|c|c|c|c|c|c|c|}
\hline $\begin{array}{c}\text { Total dose taken } \\
\mathrm{mg} / \mathrm{kg}\end{array}$ & $0.61-1.25$ & $1.3-2.5$ & $2.6-5.0$ & $6.0-10.0$ & $11.0-20.0$ & $21.0-40.0$ & $41.0-80.0$ & $81.0-160.0$ & $161.0-200.0$ \\
\hline $\begin{array}{l}\text { No. of dead } \\
\text { mice/tested }\end{array}$ & $0 / 5$ & $2 / 2$ & $6 / 8$ & $6 / 6$ & $3 / 4$ & $6 / 7$ & $8 / 10$ & $4 / 6$ & $0 / 2$ \\
\hline
\end{tabular}

Furthermore, in some individuals the hemorrhages were also observed in the brain, the abdominal cavity, the thoracic cavity, the heart, the liver, the testicles, the kidneys and the hypodermic area.

c) Subacute toxicity of diphacinone baits against the albino rats: The acceptance of diphacinone baits in albino rats was good and the intake amount per day at $0.005 \%$ was equal to that of the plain baits for the first 3 days but decreased afterwards. At 0.001 and $0.0005 \%$, the intake amount of diphacinone baits per day was equal to that of the plain baits for 5 days. As shown in Table 6 , the minimum lethal feeding periods necessary to get $100 \%$ mortality were 3 and 4 days at 0.005 and $0.001 \%$, respectively. At $0.0005 \%, 90 \%$ mortality was obtained by feeding for 5 days. Accordingly, the diphacinone concentration necessary to get $100 \%$ mortality by feeding for 5 days should be in the range between $0.001 \%$ and 0.0005 $\%$. In terms of the lethal dose, the total minimum intake dose necessary to get $100 \%$ mortality in the 5-day test ranges from 2.0 to $2.8 \mathrm{mg} / \mathrm{kg}$. As total intake dose increased, the feeding period for obtaining $100 \%$ mortality decreased. The death usually occurred from 4 to 7 days in these tests irrespective of diphacinone concentration.

In many individuals of the dead albino rats, the hemorrhages were observed in the stomach, the intestine, the liver, the lungs, the abdominal cavity and the reproductive organs.

\section{Discussion}

The acute toxicities of coumarin and indandione rodenticides against rats and mice are given in Table 7 . The $\mathrm{LD}_{50}$ values of either diphacinone or warfarin varied remarkably according to the investigators. The male rats are more resistant against diphacinone and warfarin than the females, whereas there is no sex difference in mice

Table 6 Subacute toxicity of diphacinone baits against albino rats in continuous feeding for various days

\begin{tabular}{|c|c|c|c|c|c|c|c|}
\hline Sex & $\begin{array}{c}\text { Diphacinone } \\
\text { concentration } \\
\%\end{array}$ & $\begin{array}{c}\text { Feeding days } \\
\text { of poison } \\
\text { baits }\end{array}$ & $\begin{array}{c}\text { Total intake } \\
\text { of poison } \\
\text { baits } \\
\mathrm{g} \text { (wet base) } \\
\mathrm{m} . \pm \text { S.D. }\end{array}$ & $\begin{array}{c}\text { Dose taken } \\
\text { per day } \\
\mathrm{mg} / \mathrm{kg} / \text { day } \\
\mathrm{m} . \pm \mathrm{S} . \mathrm{D} .\end{array}$ & $\begin{array}{l}\text { Total dose } \\
\text { taken } \\
\mathrm{mg} / \mathrm{kg}, \\
\mathrm{m} . \pm \mathrm{S} . \mathrm{D} .\end{array}$ & $\begin{array}{l}\text { No. of dead } \\
\text { rats/tested }\end{array}$ & $\begin{array}{l}\text { Survival time } \\
\text { Days, m. } \pm \\
\text { S.D. }\end{array}$ \\
\hline \multirow{4}{*}{$\hat{o}$} & \multirow{4}{*}{0.005} & 2 & $70.4 \pm 4.4$ & $3.58 \pm 0.36$ & $7.2 \pm 0.7$ & $4 / 5$ & $6.3 \pm 1.6$ \\
\hline & & 3 & $110.9 \pm 6.7$ & $3.67 \pm 0.24$ & $11.0 \pm 0.7$ & $5 / 5$ & $6.2 \pm 1.5$ \\
\hline & & 4 & $134.1 \pm 10.8$ & $3.35 \pm 1.76$ & $13.4 \pm 1.3$ & $5 / 5$ & $7.0 \pm 1.7$ \\
\hline & & 6 & $147.3 \pm 25.1$ & $4.54 \pm 0.57$ & $22.4 \pm 3.2$ & $5 / 5$ & $5.2 \pm 1.2$ \\
\hline \multirow{4}{*}{ 우 } & \multirow{4}{*}{0.005} & 2 & $58.4 \pm 10.2$ & $3.99 \pm 0.92$ & $8.0 \pm 1.3$ & $3 / 5$ & $7.3 \pm 2.6$ \\
\hline & & 3 & $101.4 \pm 12.1$ & $5.14 \pm 0.62$ & $15.4 \pm 1.8$ & $5 / 5$ & $5.8 \pm 1.3$ \\
\hline & & 4 & $113.4 \pm 4.6$ & $4.53 \pm 0.34$ & $18.1 \pm 1.4$ & $5 / 5$ & $6.4 \pm 0.8$ \\
\hline & & 6 & $125.8 \pm 32.1$ & $5.08 \pm 0.69$ & $24.0 \pm 3.0$ & $5 / 5$ & $5.0 \pm 1.1$ \\
\hline \multirow{2}{*}{$\hat{o}$} & \multirow{2}{*}{0.001} & 3 & $84.6 \pm 11.4$ & $0.60 \pm 0.06$ & $1.8 \pm 0.2$ & $3 / 5$ & $5.3 \pm 1.2$ \\
\hline & & 4 & $147.6 \pm 5.6$ & $0.69 \pm 0.08$ & $2.8 \pm 0.3$ & $5 / 5$ & $6.4 \pm 1.0$ \\
\hline \multirow{2}{*}{$\hat{o}$} & \multirow{2}{*}{0.0005} & 4 & $104.1 \pm 4.6$ & $0.38 \pm 0.02$ & $1.5 \pm 0.1$ & $3 / 5$ & $5.3 \pm 0.5$ \\
\hline & & 5 & $133.2 \pm 11.9$ & $0.40 \pm 0.05$ & $2.0 \pm 0.0$ & $4 / 5$ & $6.3 \pm 0.4$ \\
\hline
\end{tabular}


Table 7 Acute toxicities of indircect anticoagulant rodenticides against rats and mice

\begin{tabular}{|c|c|c|c|c|}
\hline $\begin{array}{l}\text { Test } \\
\text { compounds }\end{array}$ & Species & $\begin{array}{l}\text { Routes of adminis- } \\
\text { tration }\end{array}$ & $\begin{array}{c}\mathrm{LD}_{50} \\
\mathrm{mg} / \mathrm{kg} \pm \mathrm{S} . \mathrm{E}\end{array}$ & Investigators \\
\hline \multirow[t]{4}{*}{ Diphacinone } & $\begin{array}{l}\text { Albino rats } \\
\text { Albino mice }\end{array}$ & & $\begin{array}{r}3 \\
340\end{array}$ & Correll et al., 1952 \\
\hline & $\begin{array}{l}\text { Wistar strain } \\
\text { rats }\end{array}$ & & 17 & $\begin{array}{l}\text { Bentley and Larthe, } \\
1959\end{array}$ \\
\hline & $\begin{array}{cc}\text { Wistar strain } & \text { ㅇ } \\
\text { rats } & \hat{\jmath} \\
\text { Mice } & \text { ㅇ } \\
& \hat{o}\end{array}$ & $\begin{array}{l}\text { Oral } \\
\text { " } \\
\prime \prime \\
\prime \prime\end{array}$ & $\begin{array}{c}2.70 \\
1.93 \\
500\left(\mathrm{LD}_{10}\right) \\
100\left(\mathrm{LD}_{20}\right)\end{array}$ & Hattori, 1972 \\
\hline & $\begin{array}{ll}\text { Wistar strain } & \text { ㅇ } \\
\quad \text { rats } & \hat{0} \\
\text { dd-strain } & \text { + } \\
\text { mice } & \hat{0}\end{array}$ & $\begin{array}{l}\text { Oral } \\
\text { " } \\
\text { " } \\
\text { " }\end{array}$ & $\begin{array}{l}22.7(19.6-26.3) * \\
43.3(34.9-53.7) \\
28.3(25.0-32.0) \\
30.0(26.0-34.7)\end{array}$ & $\begin{array}{l}\text { Kusano, the present } \\
\text { paper }\end{array}$ \\
\hline $\begin{array}{l}\text { Diphacinone, } \\
\text { Chlorophacinone }\end{array}$ & Mice & Oral & $250-300$ & Ito and Tanaka, 1972 \\
\hline $\begin{array}{l}\text { Warfarin, Fumarin, } \\
\text { Coumatetralyl }\end{array}$ & Mice & Oral & $700-950$ & \\
\hline Na-warfarin & 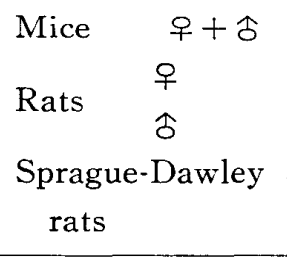 & $\begin{array}{l}\text { Oral } \\
\prime \prime \\
\prime \prime \\
\text { Intraperitoneal } \\
\prime \prime\end{array}$ & $\begin{array}{c}374 \pm 84 \\
58 \pm 18 \\
323 \pm 70 \\
2.7 \pm 0.6 \\
8.2 \pm 2.0 \\
\end{array}$ & $\begin{array}{l}\text { Hagan and Radomski, } \\
1953 \\
\text { Pyärälä, } 1968\end{array}$ \\
\hline Warfarin & $\begin{array}{l}\text { Albino rats } \\
\text { Albino rats }\end{array}$ & Oral & $\begin{array}{l}60 \\
14.5-20.0\end{array}$ & $\begin{array}{l}\text { Geigy, } 1951^{* *} \\
\text { Wilk, } 1957\end{array}$ \\
\hline Coumachlor & Norway rats & Oral & $900-1200$ & $\begin{array}{l}\text { Reiff and Wiesemann, } \\
1951\end{array}$ \\
\hline Fumarin & $\begin{array}{l}\text { Albino rats } \\
\text { Rats }\end{array}$ & & $\begin{array}{l}200 \\
400\end{array}$ & $\begin{array}{l}\text { Bentley and Larthe, } 1959 \\
\text { British Patent } \\
\text { Specification, } 1955^{* * *}\end{array}$ \\
\hline
\end{tabular}

* 95\% confidence limits, ** Cited fromWilk (1957), *** Cited from Bentley and Larthe (1959).

in the acute toxicities of these two indirect anticoagulants. Except the result of warfarin obtained by Wilk (1957), diphacinone was more acutely toxic to rats and mice than warfarin, its sodium salt, coumachlor and fumarin. The present result on the $\mathrm{LD}_{50}$ values of diphacinone against both sex of rats was remarkably higher than that of Hattori (1972a), whereas the former on the $\mathrm{LD}_{50}$ values of diphacinone against both sex of mice was lower than the latter (1972b: with both sex of mice. Also the result of Ito and Tanaka (1972) on the $L_{50}$ values of diphacinone against mice was similar to that of Correll et al. (1952) but 10 times higher than the present result.

To survey the subacute toxicity is apparently more useful for the practical use of an indirect anticoagulant as a rodenticide. The subacute toxicities of indirect anticoagulant rodenticides obtained by several researchers are given in Table 8 . It might be recognized that the subacute toxicity of diphacinone determined by the 5 -day test was approximately the same as that of coumatetralyl. Saunders et al. (1955) indicated that diphacinone was more toxic to albino rats than warfarin and pival. Bentley and Larthe (1959) had shown that diphacinone at $0.0025 \%$ and fumarin at $0.025 \%$ 
Table 8 Subacute toxicities of indirect anticoagulant rodenticides against albino rats

\begin{tabular}{|c|c|c|c|c|}
\hline \multirow{2}{*}{ Test compounds } & \multirow{2}{*}{$\begin{array}{l}\text { Feeding } \\
\text { days }\end{array}$} & \multicolumn{2}{|c|}{ Subacute toxicity $\left(\mathrm{LD}_{50}\right)$} & \multirow{2}{*}{ Investigators } \\
\hline & & $\mathrm{mg} / \mathrm{kg} /$ day & $\mathrm{mg} / \mathrm{kg} / 5$ days & \\
\hline Warfarin & 5 & 3.4 & 17.5 & Steiniger, 1953 \\
\hline Warfarin & 5 & 0.8 & 4 & Wilk, 1957 \\
\hline Fumarin & 5 & 1.4 & 7.0 & Steiniger, 1953 \\
\hline Coumatetralyl & 5 & $\begin{array}{l}0.3 \\
0.5-0.75\end{array}$ & $\begin{array}{l}1.5 \\
2.5-3.75\left(\mathrm{LD}_{100}\right) \\
\end{array}$ & Hermann and Hombrecher, 1962 \\
\hline Diphacinone & 5 & $0.4-0.69$ & $2.0-2.8\left(\mathrm{LD}_{100}\right)$ & Kusano, the present paper \\
\hline
\end{tabular}

were as toxic to Norway rats as warfarin at $0.005 \%$. The subacute toxicities of 0.025 $\%$ warfarin and $0.0125 \%$ diphacinone against house mice were approximately the same and these poisons were more toxic than $0.025 \%$ fumarin. Rowe and Redfern (1968a) obtained the similar results in the comparative test on the subacute toxicity of 0.0125 $\%$ diphacinone and $0.025 \%$ warfarin against house mice. Grolleau (1971) showed that fumarin, coumatetralyl and diphacinone had approximately the same subacute toxicity but higher than warfarin against field vole, Microtus arvalis (Pallas) at $0.0075 \%$ by the 3-day test. On the contrary, Hayes and Gaines (1959) indicated that warfarin was more effective against Norway rats, house rats and house mice than diphacinone, pival and couma chlor.

Although diphacinone showed the high toxic effect against mice in the wide range from $0.0005 \%$ to $0.02 \%$ in the present experiments, a few mice tolerated to the toxic action after feeding the large dose of diphacinone. This result suggests that a few mice might be natively refractory to the subacute toxicity of diphacinone. Such a view may be supported by the following findings. When breeding and selection treatments of laboratory mice with warfarin were carried out over several generations, some mice of warfarin resistance were selected and were inherited (Roll, 1966). Rowe and Redfern (1968b) showed that normal house mice developed a tolerance to repeated daily injections of low dose of warfarin but not to the higher doses.

Ito and Tanaka (1972) showed that the subacute toxicity of diphacinone administered with a stomach catheter was more effective against rats than mice. This was confirmed by the results of the present experiments. However, the subacute toxicities of diphacinone baits against rats and mice obtained by Hattori (1972 a, b) tended to be higher than those of the author.

\section{ACKNOWLEDGEMENTS}

The author express his gratitude to Chugai Pharmaceutical Company, Ltd., for providing 0.1 $\%$ concentrate of diphacinone. The author is also indebted to Mr. Y. Oshima in author's laboratory for his kind assistance in carrying out the present experiments.

\section{REFERENCES}

Bentley, E. W. and Y. Larthe (1959): The comparative rodenticidal efficiency of five anticoagulants. J. Hyg., Camb., $57(2)$ : 135-149.

British Patent Specification (1955): Brit. Pat. Spec. No. 734, 143, 3 pp.

Correll, J. T., L. L. Coleman, S. Long and R. F. Willy (1952) : Diphenylacetyl-1,3-indandione as a potent hypoprothrombinemic agent. Pro. Soc. Exp. Biol. and Med., N. Y., 80 : 139-143.

Drummond, D. C. (1971): Warfarin-resistant rats-some practical aspects. Pans, $17: 5-8$.

Greaves, J. H. (1971): Resistance to anticoagulants in rodents. Pestic. Sci., 2 : 276-279.

Grolleau, G. (1971) : Comparison de la toxicité de divers raticides anticoagulants à l'égard du campagnol des champs, Microtus arvalis (Pallas). Ann. Zool. Ecol. Anim., 3(2) : 261-267.

Hagan, E. C. and J. L. Radomski (1953): The toxicity of 3-(acetonylbenzyl)-4-hydroxycoumarin (warfarin) to laboratory animals. J. Am. Pharm. Ass., 42 (6) : 379-382.

Hayes, W. J. and T. B. Gaines (1959): Laboratory studies of five anti-coagulant rodenticides. Pub. Hlth. Rep., Wash., 74(2) : 105-113. 
Hermann, G. and S. Hombrecher (1962) : Control of rats and mice with Racumin ${ }^{\mathbb{B}} 57$ products. Pflanzenschutz. Nachrichten "Bayer", 15 : 89-108.

Hattori, K. (1972a) : Test of the new anticoagulant rodenticide "Diphacin 120". Part 1. Effects against albino rats. Hokkaidoritsu Eisei Kenkyu Shoho $1972(22)$ : 75-78 (in Japanese'.

Hattori, K. (1972b) : Test of the new anticoagulant rodenticide "Diphacin 120". Part 2. Effects against laboratory mice. Hokkaidoritsu Eisei Kenkyu Shoho $1972(22): 79-82$ (in Japanese).

Ito, H. and I. Tanka (1972) : Comparative toxicities of some indirect anticoagulant rodenticides. Jap. J. Sanit. Zool., 23(4):316 (in Japanese).

Jackson, W. B. and D. Kaukei (1972): Resistance of wild Norway rats in North Carolina to warfarin rodenticide. Science, 176 (4041) : 1343-1344.

Kusano, T. (1969): Studies on the improved effectiveness of anticoagulative rodenticides on rodents I. Synergistic toxic action between coumarin or indandione derivatives and thallium salts on mice. J. Facul. Agr. Tottori Univ., $52: 15-52$.

Pyärälä, K. (1968) : Sex difference in the clotting factor response to warfarin and in the rate of warfarin metabolism in the rat. Ann. Med. Exp. Fenn., $46: 23-34$.

Reiff, M. and R. Wiesemann (1951): Untersuchungen über ein neues Rodentizid mit kumulativer Wirkung auf Basis der Cumarin-Derivate. Acta Trop., 8(2) : 97-130.

Roll, R. (1966) : Über die Wirkung eines Cumarinprapärates (Warfarin) auf Hausmäuse (Mus musculus L.). Z. Angere. Zool., 53 : 277-349.

Rowe, F. P. and R. Redfern (1968a) : Laboratory studies on the toxicity of anti-coagulant rodenticides to wild house mice (Mus musculus L.). Ann. Appl. Biol., 61 : 322-326.

Rowe, F. P. and R. Redfern (1968b) : The effect of warfarin on plasma clotting time in wild house mice (Mus musculus L.). J. Hyg., Camb., 66 : 159-174.

Saunders, J. P., S. R. Heisey, A. D. Goldstone and E. C. Bay (1955): Comparative toxicities of warfarin and some 2-acyl-1,3-indandiones in rats. J. Agr. Food Chem., $3: 762-765$.

Steiniger, F. (1953) : Über die Wirksamkeit des "Fumarin" eines neuen Antikoagulans zur Rattenbekämpfung, und seine Verträglichkeit für Haustiere. Nachbl. deut. Pflanzenschutzdienstes (Stuttgart), $5:$ 167-168.

Wilk, W. (1957): Vergleichende pharmakologische und toxikologische Prüfung von Schillirosid-, Alpha-Naphthylthioharnstoff und Cumarin-Präparaten. Z. Angew. Zool., $44:$ 419-446.

$$
\begin{gathered}
\text { 摘 要 } \\
\text { ダイファシノン (2-diphenylacetyl-1,3- } \\
\text { indandione) の実験用ネズミ類に } \\
\text { 効する毒性 }
\end{gathered}
$$

インダンジオン系新殺鼠剂ダイファシノンを実用化す る基礎資料を得るため，実験用ネズミ類に対する毒性を 調查した。

ラットに対する経口急性毒性 $\left(\mathrm{LD}_{50}\right)$ は雌雄でそれぞ れ $22.7,43.3 \mathrm{mg} / \mathrm{kg}$ で, 雄は雌よりもほぼ 2 倍ほど強 い.マウスに対するそれは雌雄でそれぞれ $28.3,30.0$ $\mathrm{mg} / \mathrm{kg}$ で，性差はなかった。

ラットにダイファシノン $0.05 \sim 1.0 \mathrm{mg} / \mathrm{kg} /$ 回を 24 恃 間毎に 6 回投与したが死亡率怟かった. そこでダイフ アシノン含有毒飭のラットおよびマウスに対する亜急性 毒性孛調查した. $0.0005 〜 0.02 \%$ の゙イファシノン餌 をマウスに 6 日間連日捸食させ $60 \sim 100 \%$ 死亡率を得 た. ラットでは $0.0005 \sim 0.005 \%$ のダイファシノン慨を $2 \sim 6$ 日間連続掑食させた場合の死亡率を調查し，クマ テトラリルとほぼ同等の亜急性毒性を示すことを明らか にした：これらの試験で多くのマウス，ラットは第1回 投薬後 4〜 7 日間で死亡した. またダイファシノン慨に 対寸るネズミ類の攝取性は良好であった。

本実験で得られたダイファシノンのネズミに対する急 性, 亜急性毒性は他のクマリン系, インダンジオン系殺 鼠剂のそれらと比較，諭議した。 